\title{
Home storage of biological medications administered to patients with rheumatic diseases
}

\author{
Glaucia Santin ${ }^{1,2^{*}}$ (D) Mariana Moreira Magnabosco da Silva², Vinicius Augusto Villarreal' ${ }^{2}$, Leane Dhara Dalle Laste ${ }^{2}$, \\ Eduardo de Freitas Montin², Luis Eduardo Ribeiro Betiol ${ }^{2}$ and Valderilio Feijó Azevedo ${ }^{1,2}$
}

\begin{abstract}
Background: The inadequate storage of biopharmaceuticals may result in an ineffective therapeutic response since poor conservation can lead to the emergence of protein aggregates and cause immunogenicity in patients, which can increase the risk of adverse events by inducing the production of anti-drug antibodies. This can also lead to significant economic losses for public health, given the high cost of these medicines. The aim of this study was to verify whether the home storage of biopharmaceuticals dispensed by the Unified Public System was in accordance with the manufacturers' specified standards and whether external variables interfered with the correct home storage.
\end{abstract}

Methods: This was a prospective observational study. Patients with a confirmed diagnosis of rheumatoid arthritis, ankylosing spondylitis or psoriatic arthritis who were using a biologic exclusively dispensed by Unified Public System were included. Storage temperature was measured by digital thermometer inserted into the refrigerator of the participant's home. Fisher's exact test was performed to cross-reference the temperature data and the qualitative variables obtained using an epidemiologic questionnaire. Mean, minimum, maximum values and standard deviation were described in the quantitative data. Mann-Whitney non-parametric test was performed to the association between temperature excursion and the number of people in the house.

Results: A total of 81 participants were included and 67 (82.71\%) did not maintain home storage correctly. The maximum temperature observed among all patients was $15.5^{\circ} \mathrm{C}$, the minimum was $-4.4^{\circ} \mathrm{C}$ and the average was $5.6^{\circ} \mathrm{C}$ (standard deviation 2.8); 10 (12.3\%) had at least one negative temperature measured. The average time for participants who had an inadequate temperature record was $8 \mathrm{~h}$ and $31 \mathrm{~min}$. Nine participants (90\%) who stored the medication into the shelf/drawer below the freezer had a temperature excursion $(p=0.011)$. Most of the participants (88.5\%) who stored their biopharmaceutical near the back side, close to the wall of the refrigerator had a negative temperature record $(p<0.001)$.

Conclusion: Most of the study participants (82.71\%) did not maintain adequate home storage conditions for their biopharmaceutical. Intrinsic factors of household refrigerators may be involved in temperature deviations.

Keywords: Biological drugs, Home storage, Rheumatic diseases

\footnotetext{
* Correspondence: glaucia farma@hotmail.com

'Edumed Educação em Saúde, Rua Bispo Dom José, 2495, Curitiba, Paraná 80440-080, Brazil

Universidade Federal do Paraná, Rua General Carneiro 181, Curitiba, Paraná 80060-900, Brazil
}

(c) The Author(s). 2020 Open Access This article is licensed under a Creative Commons Attribution 4.0 International License, which permits use, sharing, adaptation, distribution and reproduction in any medium or format, as long as you give appropriate credit to the original author(s) and the source, provide a link to the Creative Commons licence, and indicate if changes were made. The images or other third party material in this article are included in the article's Creative Commons licence, unless indicated otherwise in a credit line to the material. If material is not included in the article's Creative Commons licence and your intended use is not permitted by statutory regulation or exceeds the permitted use, you will need to obtain permission directly from the copyright holder. To view a copy of this licence, visit http://creativecommons.org/licenses/by/4.0/. 


\section{Background}

The introduction of biologic drugs changed the treatment dramatically for patients with inflammatory rheumatic diseases [1] such as rheumatoid arthritis (RA), ankylosing spondylitis (AS) and psoriatic arthritis (PsA). Despite the increased number of biopharmaceutical options, a high proportion of patients is refractory to the available drugs [2]. A possible cause for the refractory treatment is the alterations in drug properties due to inadequate storage. It can compromise the stability and affect the characteristics of biopharmaceuticals, leading to human health risks. Conformational changes in the complex protein structure of biological products as a result of freezing-thawing or prolonged storage at high temperatures can lead to denaturation, irreversible formation of protein aggregates and loss of drug activity. Depending on the characteristics of the drug, the temperature and the duration of the exposure to this temperature can also cause significant economic losses to public health, given the high cost of these drugs $[3,4]$.

The presence of protein aggregates, which cause instability commonly observed in biopharmaceuticals or other protein drugs and are a major concern because they can influence the biodistribution and efficacy of the medication and may directly affect patient safety as the potential for adverse immune reactions is increased [5-7]. Protein aggregation can be induced by a wide variety of conditions, including temperature, mechanical stress, such as agitation and movement, freezing and/or thawing, and the drug formulation itself [3].

A likely explanation for the refractory treatment is immunogenicity, a complex phenomenon that depends on the interaction between several factors related to the drug and the patient. All biopharmaceuticals are potentially immunogenic and are also capable of inducing the production of anti-drug antibodies (ADAs) [2, 8, 9], which has been identified as an important (albeit not the only) contributor to treatment failure and increased risk of adverse events (AEs) in patients receiving biologic therapy [10-13].

Currently, all biologicals represent only $4 \%$ of the drugs distributed by the Unified Public System but cost $51 \%$ of the purchase budget [14]. The cold chain, a term used to describe the exact temperature conditions in which some products need to be kept during the storage, distribution and administration processes [15], is essential to ensure the quality of medicines. However, the cold chain is interrupted and sanitary control ceases at the time of dispensing the drug to the patient.

Considering this context, the objective of this study was to evaluate the domestic storage conditions in relation to the temperature range recommended by the manufacturer and to analyze possible variables that could influence the variation in refrigerator temperatures.

\section{Methods}

\section{Study design and population}

This was a prospective observational study.

The study population consisted of individuals $\geq 18$ years old, diagnosed with RA, AS or PsA, who were using a biological drug (adalimumab, etanercept, golimumab, secukinumab, certolizumab or abatacept) dispensed exclusively by the Unified Public System. Patients who used intravenous biological drugs were excluded. The biological agents chosen to be part of this project must be stored, handled and administered correctly within the temperature range of 2 to $8^{\circ} \mathrm{C}$, according to the manufacturers' specifications. Patients were identified and recruited from a database of the Complex of the Clinical Hospital of the Federal University of Paraná (Portuguese acronym: CHC/UFPR), specifically in the Spondyloarthritis Outpatient Clinic and the Centro de Pesquisas Clínicas Edumed - Educação em Saúde S/S Ltda. (Edumed Clinical Research Center - Health Education).

A total of 131 patients were selected. Of these, 50 patients were excluded, 10 for not storing the biological medication in their household, 8 for no longer using biological medication, 8 because they resided in a region with difficult access, 14 patients due to communication difficulties, and 10 due to dropping out of the study. A total of 81 patients met the eligibility criteria.

\section{Thermometers}

The TagTemp Stick ${ }^{\odot}$ is a small $(78 \times 23 \times 10 \mathrm{~mm})$, compact, robust and validated electronic temperature data logger that does not require the use of cables for operation and data collection. It connects directly to the USB interface of Windows computers for communication with $\operatorname{LogChartII}^{\circ}$, the configuration and data analysis software for TagTemp data loggers. It has an internal temperature sensor that has great accuracy. The temperature measurement range varies from $-20.0^{\circ} \mathrm{C}$ to $70.0^{\circ} \mathrm{C}$ and has a memory capacity of 32,000 (32 k) records [16].

\section{Data collection}

The researchers and the participants scheduled appointments for the implantation and removal of the thermometer in the refrigerator of the participant's home. Communication with participants was made by phone or electronic messages or in person. At each participant's residence, the informed consent form (ICF) was signed, and additional information was collected through questionnaires regarding socioeconomic level and habits regarding home medication storage. The variables on medication storage habits were collected through data of the refrigerator such as brand, model, volume and whether it had an alarm or not; number of people living at the same house as the patient, classified by sex and 
age group; time when the refrigerator door is most frequently opened; storage location of the biological drug within the refrigerator; occurrence of food stored in the same medication compartment; storage of warm food in the same refrigerator as the biological drug; how the patient was oriented to store the medication for the first time of use and which health professional transmitted this information; occurrence of electric power outage, for how long and what action patient took if it had happened. The socioeconomic variables were verified through level of education of the participant, monthly family income, employment status and employee job class (hours per week).

The thermometers were inserted inside the participant's refrigerator by the research team, and the participant was instructed to maintain the normal family routine regarding refrigerator use.

Thus, data were collected on temperature variations in each participant's refrigerator at home, in which he or she stored biological medication for 3 consecutive days next to the TagTemp Stick Novus ${ }^{\circ}$. The temperature was measured continuously for 3 consecutive days every $30 \mathrm{~s}$. The total measurement time was the period between the first and the last temperature measurement. The time period was programmed by the team using the thermometer software.

A single temperature measurement outside the ideal storage range, which should be between 2 and $8^{\circ} \mathrm{C}$, was considered a temperature excursion. Cases with negative temperature readings were those that had at least one evaluation with a negative temperature during the follow-up period.

The period of data collection was from August 2017 to March 2019.

\section{Statistical analyses}

For the statistical analyses, Fisher's exact test was used to cross-reference the temperature data and the qualitative variables obtained using the questionnaires. For the description of quantitative variables, the statistics of mean, minimum and maximum values and standard deviation were considered. To evaluate the association between temperature excursion and the number of people in the house, the Mann-Whitney non-parametric test was considered. To evaluate the association between temperature excursion and the patient's age, Student's T test for independent samples was considered. A value of $p<0.05$ was considered statistically significant.

\section{Results}

Temperatures measurements

Eighty one patients were included (Table 1). A total of $39(48.14 \%)$ men and 42 (51.85\%) women were selected. The mean age of the men was 48.38 years old, and the mean age of the women was 54.10 years old. The mean time since diagnosis was 9.38 years for men and 12.74 years for women. Regarding the underlying disease, 7 (8.6\%) men and 4 (4.9\%) women had PsA; 4 (4.9\%) men and $21(25.9 \%)$ women had RA; and 28 (35\%) men and 17 (21\%) women had AS.

Of the 81 participants (Table 2), 67 (82.71\%) recorded temperature excursions. The remaining $14(17.29 \%)$ had no temperature excursions. Ten $(12.3 \%)$ recorded at least one negative temperature measured during the period; among the cases with negative temperature readings, the mean was $-0.68^{\circ} \mathrm{C}$. For all measurements, the maximum and minimum temperatures were $15.5^{\circ} \mathrm{C}$ and $-4.4^{\circ} \mathrm{C}$, respectively; the mean temperature was $5.6^{\circ} \mathrm{C}$. Standard deviation for mean temperature is $2.8^{\circ} \mathrm{C} ; 52$ participants $(64.2 \%)$ recorded temperatures $>8^{\circ} \mathrm{C} ; 23$ participants $(28.4 \%)$ recorded a temperature $<2{ }^{\circ} \mathrm{C}$. The average duration of inadequate temperature for participants who had an inadequate temperature record was 8 $\mathrm{h}$ and $31 \mathrm{~min}$. It was found that $64.2 \%$ of our sample recorded a temperature $>8^{\circ} \mathrm{C}$.

\section{External variables versus temperature excursion}

All variables described below were associated with a temperature excursion.

Regarding the storage of food in the same refrigerator as biopharmaceuticals, it was observed that all participants who stored their biopharmaceutical with food had at least one temperature excursion, but no statistically significant differences were found $(p>0.05)$.

Regarding the association between storage location of the medication in the refrigerator (Table 3), here was a greater chance of temperature excursion in some locations within the refrigerator, and this result was statistically significant $(p<0.05)$.

To evaluate the association between the storage location within the refrigerator and negative temperatures (Table 4), the results show that there may be a greater chance of negative temperatures, with statistical significance $(p<0.05)$, in some locations with the refrigerator.

Table 1 Profile of patients in the sample

\begin{tabular}{lll}
\hline Data & Male & Female \\
\hline Number & 39 & 42 \\
Average age (years) & 48.38 & 54.10 \\
Standard deviation for age & 10.69 & 15.27 \\
Mean time since diagnosis (years) & 9.38 & 12.74 \\
Standard deviation for time since diagnosis & 6.15 & 8.38 \\
Psoriatic Arthritis Patients & 7 & 4 \\
Rheumatoid Arthritis Patients & 4 & 21 \\
Ankylosing Spondylitis Patients & 28 & 17 \\
\hline
\end{tabular}


Table 2 Patient proportion according to temperature measurements

\begin{tabular}{|c|c|c|c|c|c|c|c|}
\hline $\begin{array}{l}\text { Total } \\
\text { number of } \\
\text { patients }\end{array}$ & $\begin{array}{l}\text { Patients who had } \\
\text { temperature } \\
\text { excursion }\end{array}$ & $\begin{array}{l}\text { Patient who had at least } \\
\text { one negative temperature } \\
\text { measurement }\end{array}$ & $\begin{array}{l}\text { Maximum } \\
\text { temperature } \\
\text { measured }\end{array}$ & $\begin{array}{l}\text { Minimum } \\
\text { temperature } \\
\text { measured }\end{array}$ & $\begin{array}{l}\text { Average } \\
\text { temperature of } \\
\text { all patients }\end{array}$ & $\begin{array}{l}\text { Patients whose } \\
\text { temperature } \\
\text { was }>8^{\circ} \mathrm{C}\end{array}$ & $\begin{array}{l}\text { Patients whose } \\
\text { temperature was } \\
<2{ }^{\circ} \mathrm{C}\end{array}$ \\
\hline 81 (100\%) & 67 (82.71\%) & 10 (12.3\%) & $15.5^{\circ} \mathrm{C}$ & $-4.4^{\circ} \mathrm{C}$ & $5.6^{\circ} \mathrm{C}$ & 52 (64.2\%) & $23(28.4 \%)$ \\
\hline
\end{tabular}

The mean temperature by subgroups of storage location within the refrigerator was evaluated (Table 5). It was found that sites 6 and 7 had a mean temperature above that recommended by the manufacturers.

Other factors that did not impact the storage of medication, i.e., those that were not statistically significant $(p>$ 0.05 ), include sound alarm in the refrigerator, number of people in the house $(p=0.891)$, age of the patient $(p=$ 0.860 ), ages of the household residents ( $p$ ranged from 0.280 to 1.000 ) and refrigerator model ( $p$ value ranged from 0.722 to 1.000). The association between age and gender [with temperature excursion] was not statistically significant. In addition, there was no association between food storage in the same refrigerator and temperature deviations $(p=0.582)$ and between temperature excursion and power outages $(p=0.539)$; there was no statistical significance regarding the level of education of the patient; family income was not associated with temperature excursion; there was no statistical significance regarding the person who advised the patient $(p=0.954)$; and finally, there was no association between the time the refrigerator was opened and the temperature excursion times.

\section{Discussion}

Our results address a relevant but little understood subject by health professionals, managers and patients. One of the most notable facts in our study is that patients do not perceive temperature deviations because, in the case of patients coming from the public health system, there are no financial means and resources available to patients to measure the exact temperature of their refrigerators using an accurate thermometer. Therefore, they do not know when to adjust the temperature of their refrigerator. Periods of inadequate drug storage usually go undetected. It was observed that inadequate storage by patients was unintentional.

Previous studies have shown that the conditions of domestic storage of thermolabile therapeutics are often not adequate since less than $50 \%$ of patients stored their biopharmaceutical within the recommended temperature range $[1,17,18]$. One study [1] revealed that the age of the refrigerator is an important factor, that is, the older the appliance, the greater the risk of inadequate storage and the greater the likelihood of drug instability due to temperature variation. So we can consider that there

Table 3 Association between storage of biological medication within a refrigerator and occurrence of temperature excursions

\begin{tabular}{|c|c|c|c|c|c|}
\hline \multirow[t]{2}{*}{ Storage location within the refrigerator } & & \multicolumn{2}{|c|}{ Temperature excursion } & \multirow[t]{2}{*}{ Total } & \multirow{2}{*}{$\begin{array}{l}\text { "p" } \\
\text { value }\end{array}$} \\
\hline & & Yes & No & & \\
\hline \multirow[t]{2}{*}{0 - Shelf/drawer just below the freezer } & $\mathrm{n}$ & 9 & 1 & 10 & $0.011^{*}$ \\
\hline & $\%$ & $90.0 \%$ & $10.0 \%$ & & \\
\hline \multirow[t]{2}{*}{1 - Shelves: back side, close to the wall } & $n$ & 19 & 7 & 26 & $0.014^{*}$ \\
\hline & $\%$ & $73.1 \%$ & $26.9 \%$ & & \\
\hline \multirow[t]{2}{*}{2 - Shelves: front side } & $\mathrm{n}$ & 18 & 2 & 20 & $<0.001^{*}$ \\
\hline & $\%$ & $90.0 \%$ & $10.0 \%$ & & \\
\hline \multirow[t]{2}{*}{3 - Shelves: side, close to the wall } & $n$ & 10 & 2 & 12 & $0.019^{*}$ \\
\hline & $\%$ & $83.3 \%$ & $16.7 \%$ & & \\
\hline \multirow[t]{2}{*}{4 - Shelf/drawer above the lowest drawer (lower part of your refrigerator - lid of the vegetable drawer) } & $\mathrm{n}$ & 7 & 1 & 8 & $0.035^{*}$ \\
\hline & $\%$ & $87.5 \%$ & $12.5 \%$ & & \\
\hline \multirow[t]{2}{*}{5 - Refrigerator door } & $\mathrm{n}$ & 2 & 1 & 3 & 0.500 \\
\hline & $\%$ & $66.7 \%$ & $33.3 \%$ & & \\
\hline \multirow[t]{2}{*}{6 - In the can dispenser, if available, on the door } & $\mathrm{n}$ & 1 & 0 & 1 & $--^{* *}$ \\
\hline & $\%$ & $100.0 \%$ & $0.0 \%$ & & \\
\hline \multirow[t]{2}{*}{7 - In the can dispenser, if available, below the freezer } & $\mathrm{n}$ & 1 & 0 & 1 & $---* *$ \\
\hline & $\%$ & $100.0 \%$ & $0.0 \%$ & & \\
\hline
\end{tabular}

* Statistical significance

** Sites 6 and 7 were not considered in the table because only one case was observed and, therefore, the statistical test was not applicable 
Table 4 Association between location of biological medications within a refrigerator and occurrence of negative temperatures

\begin{tabular}{|c|c|c|c|c|c|}
\hline \multirow[t]{2}{*}{ Storage location within the refrigerator } & & \multicolumn{2}{|c|}{$\begin{array}{l}\text { Negative temperature } \\
\text { measured }\end{array}$} & \multirow[t]{2}{*}{ Total } & \multirow[t]{2}{*}{$\begin{array}{l}\text { "p" } \\
\text { value }\end{array}$} \\
\hline & & No & Yes & & \\
\hline \multirow[t]{2}{*}{0 - Shelf/drawer just below the freezer } & $\mathrm{n}$ & 8 & 2 & 10 & 0.055 \\
\hline & $\%$ & $80.0 \%$ & $20.0 \%$ & & \\
\hline \multirow[t]{2}{*}{1 - Shelves: back side, close to the wall } & $\mathrm{n}$ & 23 & 3 & 26 & $<0.001^{*}$ \\
\hline & $\%$ & $88.5 \%$ & $11.5 \%$ & & \\
\hline \multirow[t]{2}{*}{2 - Shelves: front side } & $\mathrm{n}$ & 17 & 3 & 20 & $0.001^{*}$ \\
\hline & $\%$ & $85.0 \%$ & $15.0 \%$ & & \\
\hline \multirow[t]{2}{*}{3 - Shelves: side, close to the wall } & $\mathrm{n}$ & 11 & 1 & 12 & $0.003^{*}$ \\
\hline & $\%$ & $91.7 \%$ & $8.3 \%$ & & \\
\hline \multirow[t]{2}{*}{4 - Shelf/drawer above the lowest drawer (lower part of your refrigerator - lid of the vegetable drawer) } & n & 7 & 1 & 8 & $0.035^{*}$ \\
\hline & $\%$ & $87.5 \%$ & $12.5 \%$ & & \\
\hline \multirow[t]{2}{*}{5 - Refrigerator door } & $\mathrm{n}$ & 3 & 0 & 3 & 0.125 \\
\hline & $\%$ & $100.0 \%$ & $0.0 \%$ & & \\
\hline \multirow[t]{2}{*}{6 - In the can dispenser, if available, on the door } & n & 1 & 0 & 1 & $--^{* *}$ \\
\hline & $\%$ & $100.0 \%$ & $0.0 \%$ & & \\
\hline \multirow[t]{2}{*}{7 - In the can dispenser, if available, below the freezer } & $\mathrm{n}$ & 1 & 0 & 1 & $--^{* *}$ \\
\hline & $\%$ & $100.0 \%$ & $0.0 \%$ & 1 & $--_{-}^{* *}$ \\
\hline
\end{tabular}

* Statistical significance

** Sites 6 and 7 were not considered in the table because only one case was observed and, therefore, the statistical test is not applicable

may be intrinsic characteristics of refrigerators involved in temperature deviations. However, these data were not addressed or evaluated in the present study because it would be necessary to assess technical parameters, such as the operation of home appliances, which was not the focus of our work. Patient perception and subjective reporting would be limitations of these data because of memory issues or uncertainty regarding refrigerator specifications.

Although it was not found statistically significant results regarding the aspects that could change storage, it was found that the location of the medication within the refrigerator is very important for proper storage. Storage in the refrigerator door exposes products to greater temperature variations. Our findings show that participants who stored their medication in the can dispenser on the door or below the freezer had a mean temperature of $9.0^{\circ} \mathrm{C}$, which is above that recommended by the manufacturers.

Products should be placed on shelves to allow air circulation; and for this reason, the boxes should be kept away from the wall and with a minimum spacing of 2 to $3 \mathrm{~cm}$ between them. Products that tolerate negative temperatures, which is not the case for biopharmaceuticals, should be placed on the upper shelf. To avoid freezing, these drugs should be stored on lower shelves [19]. Several authors recommend that biopharmaceuticals be stored on the middle shelf because it is believed that this

Table 5 Mean temperature by subgroups of storage location within the refrigerator

\begin{tabular}{|c|c|c|c|}
\hline Storage location within the refrigerator & $\begin{array}{l}\text { Patients included in analysis } \\
(n=81)\end{array}$ & $\begin{array}{l}\text { Mean } \\
\text { temperature }\end{array}$ & $\begin{array}{l}\text { Standard } \\
\text { deviation }\end{array}$ \\
\hline 0 - Shelf/drawer just below the freezer & 10 & 5.6 & 3.0 \\
\hline 1 - Shelves: back side, close to the wall & 26 & 4.8 & 2.4 \\
\hline 2 - Shelves: front side & 20 & 5.8 & 3.6 \\
\hline 3 - Shelves: side, close to the wall & 12 & 5.6 & 2.2 \\
\hline $\begin{array}{l}4 \text { - Shelf/drawer above the lowest drawer (lower part of your refrigerator - lid of } \\
\text { the vegetable drawer) }\end{array}$ & 8 & 6.7 & 2.9 \\
\hline 5 - Refrigerator door & 3 & 6.1 & 1.4 \\
\hline 6 - In the can dispenser, if available, on the door & 1 & 9.0 & $--^{*}$ \\
\hline 7 - In the can dispenser, if available, below the freezer & 1 & 9.1 & $--^{*}$ \\
\hline
\end{tabular}

* Standard deviation in sites 6 and 7 was not considered because only one case was observed and, therefore, this is not applicable 
is the best place in the refrigerator for maintaining the temperature between 2 and $8{ }^{\circ} \mathrm{C}$. It was found that the majority $(90 \%)$ of participants who stored medication at the front of the shelves recorded a temperature excursion, with statistical significance $(p<0.001)$. This may be due to the occurrence of exchanging hot and cold air in the opening of the refrigerator door, which causes the temperature to oscillate and, therefore, increase the incidence of temperature excursions.

For "duplex" and "frost-free" refrigerators, there must be communication between the freezing system and the storage chamber for better medication storage [19]. It was observed that $88.9 \%$ of the participants with a "duplex" refrigerator recorded a temperature excursion; however, this result was not statistically significant ( $p=$ 0.722 ). In the case of frost-free refrigerators, $76.9 \%$ recorded a temperature excursion, without statistical significance $(p=0.687)$. It was observed that some participants who stored their biopharmaceutical near the refrigerator wall, at the back part, recorded a negative temperature $(p<0.001)$, which may be because the cold air in the refrigerator may penetrate the walls, leading to freezing of items nearby.

Many participants had a sound alarm system in the refrigerator, which is activated when the refrigerator door remains open after a period of time, determined by each manufacturer, but this seems to be a nonrelevant factor for maintaining the appropriate temperature.

James et al. [20] found that many refrigerators around the world operate at temperatures higher than those recommended. Our findings show that $64.2 \%$ of our sample recorded a temperature $>8^{\circ} \mathrm{C}$.

The reasons for patients not complying with manufacturers' storage recommendations are, to a large extent, unknown. It is essential that patients receive information about the adequate storage of medications at the time of dispensing. Although most patients receive these guidelines, they expose the drugs to various unfavorable storage conditions. Patients are not always able to determine adequate storage in their homes and have problems independently administering their medications at home [21].

Because most patients did not store medications properly, in theory, it would be possible for physicians to adjust prescriptions so that they could be dispensed according to their treatment regimen (weekly, biweekly or monthly) and not for prolonged periods, as occurs with the Unified Public System, to minimize the storage time.

Another relevant factor is the existence of centers specialized in high-cost medication that aim to ensure the comprehensiveness of drug treatment at the outpatient level and, in addition, to perform the dispensing and administration of patient medication. According to the Brazilian Ministry of Health [22], the reference centers used for the administration of biological medications have greater rationality of use and monitor the effectiveness of these drugs. The rational use and monitoring of the effectiveness of these drugs can also avoid the incorrect use of these medications. Pharmacists can play a key role in promoting good storage practices, providing supervision and training patients. Since 2010, The HighCost Medication Dispensing Center (CEDMAC for its Portuguese acronym) of the Clinics Hospital of the State University of Campinas (HC-UNICAMP for its Portuguese acronym), located in the state of São Paulo, has been a reference for treatment using immunobiological agents in rheumatologic diseases; when indicated, these agents are dispensed and applied at the center so that improper or incorrect use of these medications is avoided [23].

There are no data in the literature comparing inadequate storage with adverse events and there are no evidences that inadequate storage specifically increases failure or adverse events. A full discussion of if inadequate storage can change the outcome of the patient's treatment is beyond the scope of this article. It has been widely acknowledged that temperature fluctuations increase the formation of protein aggregates and this can enhance immunogenicity by inducing the production of ADA $[24,25]$. Several studies have related the presence of ADA with adverse reaction. In other words, drug immunogenicity may also affect drug safety, increasing the risk of adverse events [26-31].

In this study, the temperature excursion was similar to that of developed countries, as it was found results similar to those of the studies discussed herein. Therefore, temperature excursion is not characterized as an independent cultural or socioeconomic factor.

It must bear in mind that patients have different levels of education and understanding; thus, one way to improve home storage would be through explanatory materials that can be provided to patients through clear and concise language, with illustrations and short text. This material may include explanations such as, the most appropriate place to store the medication within the refrigerator, the importance of keeping the medication in its primary packaging and guidelines on the medication conditions before applying it.

The strategies discussed above are very important and require mastery of the subject by the professionals involved through knowledge, training, development of new guidelines and implementation of innovations of storage systems (temperature monitoring devices). All this should be done to inform patients and ensure they can better control home storage conditions.

More research in home storage area is required to evaluate the relation between inadequate storage and the effectiveness of biologic treatment. 


\section{Conclusion}

We concluded from this study that the majority of participants included $(82.71 \%)$ did not maintain adequate home storage conditions for their biological medication and that intrinsic characteristics of home refrigerators may be involved in the temperature deviations. Temperature excursions cannot be characterized as a cultural or socioeconomic factor because our findings are similar to those of developed countries.

\section{Abbreviations \\ ADA: Anti-drug antibodies; AS: Ankylosing spondylitis; CAPES: Coordenação de Aperfeiçoamento de Pessoal de Nível Superior; CEDMAC: High-Cost Medication Dispensing Center; CHC/UFPR: Complex of the Clinical Hospital of the Federal University of Paraná; HC-UNICAMP: Clinics Hospital of the State University of Campinas; ICF: Informed consent form; PsA: Psoriatic arthritis; RA: Rheumatoid arthritis; TNF: Tumor necrosis factor}

\section{Acknowledgments}

To our patients who gently agreed to participate in this study.

\section{Authors' contributions}

VA and GS: Conception and study design; Manuscript preparation; Elaboration of article; Data analysis and interpretation; Elaboration of article and critical review; MS and W had some participation in the writing of the manuscript; All authors, except VA, performed data collection; GS had full access to all study data and takes responsibility for the integrity of the data All authors read and approved the final manuscript to be published.

\section{Funding}

This study was financed in part by the Coordenação de Aperfeiçoamento de Pessoal de Nível Superior - Brasil (CAPES) - Finance Code 001. Furthermore, this study was supported by Edumed - Educação em Saúde S/S Ltda.

\section{Availability of data and materials}

The data that support the findings of this study are available from the corresponding author, upon reasonable request.

\section{Ethics approval and consent to participate}

The study was conducted according to the ethical standards established in the Declaration of Helsinki of 1964 and its subsequent amendments and was approved by the Institution's local ethics committee (Comitê de Ética em Pesquisa em Seres Humanos do CHC/UFPR \# 66073817.0.0000.0096). All patients included in the study were fully informed about the research, and an ICF was obtained from all patients prior to their inclusion in the study.

\section{Consent for publication}

All authors are aware of the full content of the manuscript and provided consent for the submission to Advances in Rheumatology.

\section{Competing interests}

Valderilio Azevedo:

Latin American Forum on Biosimilars Coordinator; Principal Investigator in clinical trials sponsored by AbbVie Farmacêutica Ltda, Pfizer, Novartis Biociencias SA, Eli Lilly do Brasil Ltda., Boehringer Ingelheim do Brasil Química e Farmacêutica Ltda., GlaxoSmithKline do Brasil, Genentech, Inc. UCB Biopharma AS.

Received: 9 November 2019 Accepted: 30 April 2020

Published online: 27 May 2020

\section{References}

1. Vlieland ND, et al. The majority of patients do not store their biologic disease-modifying antirheumatic drugs within the recommended temperature range. Rheumatology. 2016;55(4):704-9. https://doi.org/10. 1093/rheumatology/kev394.

2. Mócsai A, Kovács L, Gergely P. What is the future of targeted therapy in rheumatology: biologics or small molecules? BMC Med. 2014;12(1):1-9. https://doi.org/10.1186/1741-7015-12-43.
3. Wang W, Nema S, Teagarden D. Protein aggregation-pathways and influencing factors. Int J Pharm. 2010;390(2):89-99. https://doi.org/10.1016/j. ijpharm.2010.02.025 Epub 2010 Feb 24.

4. Ricote-Lobera I, et al. Estabilidad de los medicamentos termolabiles ante una interrupcion accidental de la cadena de frio. Farm Hosp. 2014;38(3): 169-92. ISSN 2171-8695. https://doi.org/10.7399/FH.2014.38.3.1164.

5. Moussa EM, et al. Immunogenicity of therapeutic protein aggregates. J Pharm Sci. 2016;105(2):417-30. https://doi.org/10.1016/j.xphs.2015.11.002.

6. Mahler HC, Friess W, Grauschopf U, Kiese S. Protein aggregation: pathways, induction factors and analysis. J Pharm Sci. 2009;98(9):2909-34. https://doi. org/10.1002/jps.21566.

7. Rosenberg AS. Effects of protein aggregates: an immunologic perspective. AAPS J. 2006:8(3):E501-7.

8. Vincent FB, Morand EF, Murphy K, Mackay F, Mariette X, Marcelli C. Antidrug antibodies (ADAb) to tumour necrosis fator (TNF)-specific neutralising agents in chronic inflammatory diseases: a real issue, a clinical perspective. Ann Rheum Dis. 2013;72:165-78. https://doi.org/10.1136/annrheumdis-2012202545

9. Deehan M, Garces S, Kramer D, Baker MP, Rat D, Roettger Y, et al. Managing unwanted immunogenicity of biologicals. Autoimmun Rev. 2015;14(7):56974. https://doi.org/10.1016/j.autrev.2015.02.007 Epub 2015 Mar 2.

10. van Schouwenburg PA, Rispens T, Wolbink GJ. Immunogenicity of anti-TNF biologic therapies for rheumatoid arthritis. Nat Rev Rheumatol. 2013;9(3): 164-72. https://doi.org/10.1038/nrrheum.2013.4.

11. Jullien D, Prinz JC, Nestle FO. Immunogenicity of biotherapy used in psoriasis: the science behind the scenes. J Invest Dermatol. 2015;135(1):318. https://doi.org/10.1038/jid.2014.295.

12. Krieckaert C, Rispens T, Wolbink G. Immunogenicity of biological therapeutics: from assay to patient. Curr Opin Rheumatol. 2012;24(3):306-11. https://doi.org/10.1097/BOR.0b013e3283521c4e.

13. Garce^s S, Demengeot J, Benito-Garcia E. The immunogenicity of anti-TNF therapy in immune-mediated inflammatory diseases: a systematic review of the literature with a meta-analysis. Ann Rheum Dis. 2013;72(12):1947-55. https://doi.org/10.1136/ annrheumdis-2012-202220.

14. Da Saúde M. Espondilite anquilosante. Brasil: Protocolo Clínico e Diretrizes Terapêuticas; 2017. http://portalarquivossaudegovbr/images/pdf/2017/ agosto/03/PCDT- Accessed 18 July 2019.

15. Purssell E. Reviewing the importance of the cold chain in the distribution of vaccines. Br J Community Nurs. 2015;20(10):481-6. https://doi.org/10.12968/ bjcn.2015.20.10.481.

16. NOVUS, Produtos eletrônicos. http://www.novus.com.br/produtos/732906. Accessed 18 July 2019

17. Cuéllar MJ, et al. Calidad en la conservación de los medicamentos termolábiles en el ámbito domiciliario. Revista de Calidad Asistencial. 2010; 25(2):64-9. https://doi.org/10.1016/j.cali.2009.09.001.

18. De Jong MJ, et al. Exploring conditions for redistribution of anti-tumor necrosis factors to reduce spillage: a study on the quality of anti-tumor necrosis factor home storage. J Gastroenterol Hepatol. 2018;33(2):426-30. https://doi.org/10.1111/jgh.13920.

19. Rapkiewicz J, Grobe R. Cuidados no armazenamento de medicamentos sob refrigeração; 2014

20. James SJ, Evans J, James C. A review of the performance of domestic refrigerators. J Food Eng. 2008:87(1):2-10.

21. Sino CGM, et al. Medication management capacity in relation to cognition and self-management skills in older people on polypharmacy. J Nutr Health Aging. 2014;18(1):44-9. https://doi.org/10.1007/s12603-013-0359-2.

22. Ministério da Saúde (2018). Enquete pública de medicamentos biológicos. http://portalarquivos2.saude.gov.br/images/pdf/2018/outubro/19/ResultadoEnquete-Problemas-Versao-Publica.pdf.

23. Bértolo MB, et al. Manual de Processos de Trabalho do Centro de Dispensação de Medicação de Alto Custo (CEDMAC). Campinas: Série Manuais do Hospital de Clínicas da Unicamp; 2012. p. 16-23. https:// intranet.hc.unicamp.br/manuais/cedmac.pdf. Accessed 05 September 2019.

24. Carpenter JF, Randolph TW, Jiskoot W, et al. Overlooking subvisible particles in therapeutic protein products: gaps that may compromise product quality. J Pharm Sci. 2009:98:1201-5. https://doi.org/10.1002/jps.21530.

25. Rosenberg AS. Effects of protein aggregates: an immunologic perspective. AAPS J. 2006:8:E501-7.

26. Baert F, Noman M, Vermeire S, Van Assche G. D' Haens G, Carbonez a, et al: influence of immunogenicity on the long-term efficacy of infliximab in Crohn's disease. N Engl J Med. 2003;348:601-8. 
27. Pascual-Salcedo D, Plasencia C, Ramiro S, Nuno L, Bonilla G, Nagore D, et al. Influence of immunogenicity on the efficacy of long-term treatment with infliximab in rheumatoid arthritis. Rheumatology (Oxford). 2011;50:1445-52.

28. Wolbink GJ, Vis M, Lems W, Voskuyl AE, de Groot E, Nurmohamed MT, et al. Development of antiinfliximab antibodies and relationship to clinical response in patients with rheumatoid arthritis. Arthritis Rheum. 2006;54:7115.

29. Vultaggio A, Matucci A, Nencini F, Pratesi S, Parronchi P, Rossi O, et al. Antiinfliximab IgE and non-IgE antibodies and induction of infusion-related severe anaphylactic reactions. Allergy. 2010;65:657-61. https://doi.org/10. 1111/j.1398-9995.2009.02280.x Epub 2009 Nov 27.

30. Matucci A, Pratesi S, Petroni G, Nencini F, Virgili G, Milla M, et al. Allergological in vitro and in vivo evaluation of patients with hypersensitivity reactions to infliximab. Clin Exp Allergy. 2013;43:659-64. https://doi.org/10.1111/cea.12098.

31. Farrell RJ, Shah SA, Lodhavia PJ, Alsahli M, Falchuk KR, Michetti P, et al. Clinical experience with infliximab therapy in 100 patients with Crohn's disease. Am J Gastroenterol. 2000;95:3490-7.

\section{Publisher's Note}

Springer Nature remains neutral with regard to jurisdictional claims in published maps and institutional affiliations.

Ready to submit your research? Choose BMC and benefit from:

- fast, convenient online submission

- thorough peer review by experienced researchers in your field

- rapid publication on acceptance

- support for research data, including large and complex data types

- gold Open Access which fosters wider collaboration and increased citations

- maximum visibility for your research: over $100 \mathrm{M}$ website views per year

At BMC, research is always in progress.

Learn more biomedcentral.com/submissions 